\title{
Aspects Regarding the Possibility of Increasing the Performance of the Organization by Motivating Human Resources (HR)
}

\author{
Oana Diana LUPOAE ${ }^{\star}$, Riana Iren RADU ${ }^{\star \star}$, Rodica PRIPOAIE ${ }^{\star \star \star}$
}

\begin{tabular}{l}
\hline \multicolumn{1}{c}{ A R T I C L E I N F O } \\
\hline Article history: \\
Accepted December 2019 \\
Available online December 2019 \\
\hline JEL Classification \\
M51, M52 \\
Keywords: \\
Human resources, Motivation, \\
Loyalty program
\end{tabular}

A B S T R A C T

The present paper focuses mainly on the development of a new idea which can consolidate the relation between the Employee and the Employer. The research is based on the identification of a dimension and connection between the Financial Management and the Human Resources Management. The financial resources used for the motivation of the Human Resources can be considered at the limit between investment and non-recoverable expense. The human capital represents the most important factor for an organization; due to this, it must constantly ensure the motivation of the Human Resources. The motivation lays at the basis of the behaviors and activities which the Employees develop within an entity in close connection to the particularity of its challenges. Accordingly, in order to ensure the performance of modern companies, there is the need to know and understand the elements which motivate or demotivate an Employee. The individual and group performances are in connection to the direct implementation of the Human Resources Management; accordingly, a structural background can be created only by knowing the motivational theory and by applying efficient managerial strategies, background which can help the interests of the organization, as well as those of the Employees.

(C) 2019 EAI. All rights reserved.

\section{Introduction}

The motivation and work satisfaction represent a controversial subject approached in many studies performed in the literature from Human Resources area. The labor productivity is influenced by the effort made, by the fluctuation of the labor force or by the absenteeism, all these affecting directly the behavior on the labor market.

In various research works performed by Mc Gregor, Maslow, Likert, Herzberg or Mc. Clelland, it is demonstrated that the individual cannot be motivated at command, but only by exercising upon it a coercion or reward.

Maslow published in 1954 a volume of articles and works performed during 67 years of research under the title "Motivation and personality". The most known and controversial contents theory from the specialty literature is the theory of the hierarchy of needs, named also the theory of the pyramid of needs. The theory classifies the needs of the individuals in five known categories: physiological needs, security and safety needs, belongingness needs, esteem and social status needs and self-fulfillment needs.

McGregor, relying on Maslow's hierarchy of needs, argues that an already satisfied need does no longer motivate the individual. The theory focuses on the fact that money and benefits meet the lower rank needs of the employees, but once they are satisfied, the motivational source is lost. This means that employees could meet their higher-level needs only by increasing financial motivation. But the studies conducted internationally by specialists show that money can only motivate up to a certain level, not leading to the satisfaction of the needs of esteem, status or self-fulfillment and thus not leading to increased labor productivity. McGregor argues that an organizational environment based on command and control cannot be effective, as it focuses on meeting the needs of the lower rank as a source of motivation, and in modern society the exclusive satisfaction of these needs leads to avoidance of responsibility, to contempt towards work, to resistance to change and to not assuming the organizational objectives.

Diaz- Serrano and Cabral Vieira consider that the work satisfaction is an indicator of the status and a predictor of the goal of the Employees to remain at the place of work or to leave from it.

The Employee thinks about which is his/her contribution and what does he/she receive in exchange for his/her work from the organization. The comparison develops in two directions, one internal, within the 
company and the other one external towards the Employees from other companies. Even through this report is not the same in all countries, the thinking mechanism of the Employee is similar.

It has long been considered that the work productivity and the performance of an Employee are strictly correlated with the skills, knowledge that he/she possesses and which he/she can develop through vocational training courses. However, managers noticed that many people with intellectual potential had lower performance as compared to other less gifted colleagues. Thus, the psychologists have come to the conclusion that work efficiency is achieved only when the individual's endowment and training are supported by an internal, dynamic, directional and energizing state, which allows the individual to focus on achieving the proposed goals (Zlate 2007 , pp. 385-386), by motivation. In the 1950s, some specialists came to say that satisfaction is the only cause of performance, the theory being more intuitive.

The developed salary policy is very important in motivating the Employee, and its transparency is essential. Also, in order to be motivated, the Employees must have confidence in the Performance Assessment System applied in the organization (Florea et al., 2019b), they must know the rules according to which they are evaluated and not least, they must know the connection between contribution and remuneration.

The concrete result of a motivation is always a certain action, which depends on the person's subjective perception on what he/she considers to be satisfaction; we talk about the satisfaction seen from his/her point of view and not necessarily from the point of view of the company or of the other Employees (Muscalu, Muntean, 2012).

The motivation system ensures the connection between the reward that an employee hopes to obtain and the productivity obtained, the normal succession being: productivity - performance assessment - reward (Deaconu, 2008, p.174).

Leboye (2001) considers motivation as a decisive element of the survival of enterprises and an important source of competitiveness.

"People represent the most important resource of a company" - this is a phrase spoken so often that it has become a cliché. An important resource, of course, because the salaries and the various training courses of the Employees are clearly reflected in the costs of the companies, but can the return on the investment in the Employees be calculated with the same accuracy?

HR and Finance are strong inter-correlated because the HR strategy concerned the bonus scheme determinates the performance of organization for long-term. Thus, the employees should be treated as intangible assets that can bring Good-Will, than costs. Also, the expenses made to motivate the human resources have implications on the fiscal cost of the company.

\section{Research methodology}

The most commonly used method in the paper is the comparative method, and the arguments that justify the usage of this method consist in the fact that it allowed us to identify the similarities, but also the dissimilarities existing between Employees, Employers and Motivating Factors.

The methods of analysis in conjunction with the comparative studies, as well as with the interpretations of the specialists in the national and international specialized literature, have led to providing a faithful image of the problem addressed.

Many researchers have formulated theories and models and have tried to find answers to questions that fascinate us and which are addressed in the present paper:

Q1: "Why are people motivated to do something and what motivates them most?"

Q2: "What makes them work?" Or "What makes them to do their best?"

Q3: "Are people born self-motivated or should motivation be induced?"

Q4: "Which is the most effective method of motivating the employees appropriate for $21^{\text {st }}$ century?"

\section{Delimitations}

Employee's passing from the stage of source of certain expenses with vague productiveness to the stage of investment with exact profit has not been a subject of interest for the Romanian companies, because they consider that the investment in Human Resources cannot be concretely measured. In the past, the individual's motivation for work was limited to the very precise execution of what he/she was requested to do. The Employee's interest was simple: he/she had some work to do to earn his/her living and support his/her family.

"What makes Employees work?" or "What drives them to do their best?"

According to a survey conducted by Bestjobs, talkative colleagues, phones and endless meetings are among the reasons why three out of four Romanian Employees lose daily up to two hours of working time. According to the survey:

- $8 \%$ of employees lose up to half the working day in this way, while half of the respondents say that they avoid gossiping colleagues or that they do not join the social networks during the working hours,

- $46 \%$ state that they only answer to important and urgent calls and messages, and $13 \%$ decide to turn off their personal phone during working hours, 
- $26 \%$ of the respondents choose to respond to job-related e-mails only after they have finished their urgent tasks, and in order not to be disturbed by noise or by colleagues' discussions, $14 \%$ prefer to listen to music by headphones,

- $47 \%$ mentioned the flexible work schedule,

- $45 \%$ spoke about the need to create spaces in which they can work without being interrupted, and $24 \%$ about the need to give up the concept of "open space",

- $23 \%$ of those surveyed said they would like the Employer to offer them time management courses or to create internal policies, such as days without meetings,

- $13 \%$ of the Employees consider that the Employer should limit the time for coffee and smoking breaks,

The BestJobs research had been performed between $2^{\text {nd }}$ and $16^{\text {th }}$ August 2019 , on a sample of 926 Internet users.

According to the benchmarking study (the comparative analysis of companies) performed on the Romanian market by PricewaterhouseCoopers (PwC), the profitability of investments in human capital is higher for companies on the Romanian market than in other European countries. Thus, for every Euro invested in the salaries, benefits and training of Employees, Romanian companies earn between 0.4 and 0.6 Euros more than the rest of Europe (the difference in profitability is explained by the fact that in Romania the salary costs are lower).

The costs increase on the close labor market on the one hand, where Employee loyalty involves sometimes significant increases in salary packages, on the other hand it is about increasing the budgets allocated for training (Florea et al., 2019a).

UBD has brought in Romania the ROI Methodology (the methodology for calculating the return for investment in employees). It was launched in the US by Jack and Patty Philips in the 1970s, the founders of ROI Institute, which has expanded its network of partners in over 20 countries in the meantime.

The ROI method has five levels of measurement: the first refers to the participants' satisfaction towards the initiative taken into consideration, a satisfaction that is evaluated by a simple questionnaire; the second level is the one of assimilation - if the Employees liked it, it must be determined what they have assimilated; at the third level, the behavioral changes in the workplace following the respective initiative are measured; the fourth level measures the impact that the company has on what the Employees have assimilated and applied, and the fifth level determines the profitability of the respective initiative for the entire business, by reporting to costs. In Romania, the companies measured $1^{\text {st }}$ level, usually when they organized training programs concluded with feedback questionnaires. Some companies reached the second level - they also gave a test to the Employees, to see what and how much they had assimilated. Very few reached the third level, especially the service companies, where the customer relationship matters a lot. One example is represented by the banks, which have been applying the "mystery shopping" method for several years.

Coca-Cola HBC Romania has an annual budget of one million Euros for Employee Training Programs, whose total number is about 2,700. The company has four people in the HR Department that deals with training programs and their monitoring.

In order to calculate the profitability of the investment in people, Coca-Cola measures the evolution of some internal culture parameters, such as customer focus, teamwork or innovation. In addition, the development of skills according to plans for each Employee is regularly monitored.

Improving the quality of work and the concept of high quality work place is a fundamental objective of the European strategy in labor area, the European Employment Strategy, but also of the Lisbon Strategy.

There is an intense concern in Europe towards the degree of Employees'; satisfaction and the extent to which they are motivated to provide quality work in line with the standards imposed by organizations.

A significant indicator at European level is The European Motivation Index, an initiative of Effectory organization, one of the largest organizations concerned with workforce research in Europe.

The European Motivation Index achieves an average of the scores obtained in different countries in Europe and takes into account the direct dependence of these values on the factors that can influence the Human Resources as well as the management style, the development opportunities offered by each organization, the degree of internal communication.

The first variable considered in the presentation of the European Motivation Indicator is the Employees' commitment. The commitment allows the organization to grow and be comparative on the market, being a key variable in determining Employee Performance.

The commitment can take three forms:

- Emotional commitment - the Employee stays in the organization because he/she wants this, because he/she identifies himself/herself with the organization;

- Normative commitment - the Employee remains in the organization because he/she feels compelled to continue his/her work; 
- Long-term commitment - the Employee remains in the organization because the personal costs of his/her leaving are too high - for example, when his/her age does not allow him/her to find another job.

Following to this information, we have proposed further to perform a case study on the costs which securing the employee's loyalty would suppose for an entity.

\section{Case study}

"Which is the most efficient method of motivating the employees in the $21^{\text {st }}$ century?"

We live in the speed century, and time is the most valuable thing for us. The career has an important place both for men and women, on contrary to the past when the woman had responsibilities mainly for children education and housekeeping.

An important aid for securing the loyalty of a company's Employees is represented by building a kindergarten, where the Employees can leave their children during the working hours, without losing time in traffic with the trip to the school unit and without being concerned about searching for a babysitter.

We are going to analyze next the implications which this project can bring in what concerns building the loyalty of the Employees.

The intended purpose is the satisfaction of some emotional motivations related to the desire to contribute to the education of the young generation, aiming simultaneously to obtain profit following to the development of this type of activity.

The general objectives aim at:

- $\quad$ Recovering the initial investment and starting the program for building the loyalty of the Employees;

- Ensuring an education and care level in accordance with the customer's requirements;

- Starting the project on building and commissioning a building for the development of kindergarten activities.

The kindergarten is a service company which desire to promote pre-school education services on the market, addressing especially to the company's Employees having children and to families with average material means which grant a longer time to work (career).

The object of activity is represented by caring for and educating pre-school children, in order to develop their personality harmoniously, and to prepare them for the following steps in life.

The company's organizational chart comprises: Finance - Accounting Department, Administrative Department and Educational Department, each of them being coordinated by a Director specialized on the area in which he/she is activating. The company's management is ensured by the General Director, who is the company's Administrator.

The mission is to ensure private high quality services in an area which has been mostly institutionalized: education of pre-school children.

The strategy is based on the following key points:

- High quality services and teachers with generous experience and adequate training;

- Diversified educational and recreational programs;

- $\quad$ Food and nutritional program adequate for the age of the children, using mostly specialized catering services;

- Profitability: compelling cost control and efficient management of Income and Expense Budget.

For the development in adequate conditions of the activity, it is required a useful floor space of about 200-250 $\mathrm{m}^{2}$, respectively 6-7 rooms and utilities (kitchen, bathrooms), as well as an external playground adequately arranged.

Also, the space will be furnished in accordance with the developed activity and will be endowed with diversified educational and recreational materials. Up to the moment when the proper courses will start, the equipment necessary for the activity development must be purchased.

The institution aims at starting the didactic activity in the first year by providing educational services at kindergarten class for 40 children with ages comprised between 2 and $4 / 5$ years old, organized in 2 groups of 20 children each.

The program of the kindergarten for children is between 8:00 and 13:00 in short program mode and respectively between 8:00 and 18:30 in extended program mode.

Table no. 1

\begin{tabular}{|c|c|c|}
\hline No. & FINANCIAL INFORMATION & VALUE \\
\hline & Initial investment: & \\
\hline 1 & $\begin{array}{l}\text { Expenses incurred for the company's } \\
\text { establishment }\end{array}$ & $600 €$ \\
\hline 2 & Administrative expenses: & \\
\hline a. & $\begin{array}{l}\text { Rental of the building ( } 2 \text { months advance } \\
\text { payment } x 2,000 € \text { ) }\end{array}$ & $4,000 €$ \\
\hline
\end{tabular}




\begin{tabular}{|l|l|r|}
\hline No. & FINANCIAL INFORMATION & VALUE \\
\hline b. & Reconditioning / furnishing works & $3,000 €$ \\
\hline c. & $\begin{array}{l}\text { Purchase of equipments and materials for the } \\
\text { activity development: }\end{array}$ \\
\hline & -furniture (desks, tables, chairs, beds) & $7,000 €$ \\
\hline & -games, toys & $1,000 €$ \\
\hline & -sanitation and hygiene products & $200 €$ \\
\hline & -stationary products & $100 €$ \\
\hline & -bed sheets & $1,000 €$ \\
\hline & -computer, multifunctional printer & $1,500 €$ \\
\hline & -TV set & $1,000 €$ \\
\hline & -audio and video CDs/DVDs & $200 €$ \\
\hline & -Washing machine and clothes drier & $1,000 €$ \\
\hline & -Dish washer & $500 €$ \\
\hline & -Vacuum cleaner & $200 €$ \\
\hline & -Fridge & $300 €$ \\
\hline & -Materials and detergents for cleaning & $100 €$ \\
\hline & -Board (3 pieces) & $150 €$ \\
\hline & -Establishment of external playground & $2,000 €$ \\
\hline & -Promotion by media, flyers and Web page & $3,000 €$ \\
\hline & -Ads for selection of personnel on www.eJobs.ro & $150 €$ \\
\hline & Total of administrative expenses & $\mathbf{2 6 , 4 0 0} €$ \\
\hline & GRAND TOTAL FOR INITIAL EXPENSES & $\mathbf{2 7 , 0 0 0} €$ \\
\hline &
\end{tabular}

Table no. 2

\begin{tabular}{|l|l|r|}
\hline $\mathbf{1}$ & Monthly expenses & \\
\hline & $\begin{array}{l}\text { Expenses with salaries and contributions to } \\
\text { social security and State budget: }\end{array}$ & $\mathbf{4 , 0 0 0} €$ \\
\hline & -administrator & $1,000 €$ \\
\hline & -teacher (3 teachers x 600 & $1,800 €$ \\
\hline & -Foreign language teacher (2 teachers x 300€) & $600 €$ \\
\hline $\mathbf{2}$ & -Care-taker (2 care-takers x 300 $)$ & $600 €$ \\
\hline & Average administrative expenses & $\mathbf{6 , 2 0 0} €$ \\
\hline & -catering services (monthly cost) & $3,000 €$ \\
\hline & -Rent & $2,000 €$ \\
\hline & -Electricity & $200 €$ \\
\hline & -Gas & $300 €$ \\
\hline & -Telephone & $100 €$ \\
\hline & -Internet, TV cable & $50 €$ \\
\hline & -Stationary & $150 €$ \\
\hline & -Hygiene - sanitation products & $100 €$ \\
\hline & -Fund for recreational activities & $200 €$ \\
\hline & -Sundry expenses & $100 €$ \\
\hline & GRAND TOTAL FOR MONTHLY EXPENSES & $\mathbf{1 0 , 2 0 0 €}$ \\
\hline
\end{tabular}

The initial investment can be depreciated in about five years, according to the number of customers. Meanwhile, the monthly collections can reach to 12,000 Euro, having 40 children enrolled, with an average value of 300 Euro for the monthly fee for each child.

Discounts and reductions are applied for the children of the Employees, benefiting thus from a loyalty program, a motivating factor in making efficient their work.

\section{Conclusions}

Why are people motivated to do something and which is the biggest motivation?

The motivation methods can be many kinds - internal, external, material or non-material: recognition of efforts and achievements, benefits at work and outside it, the safety of the place of work, supporting new and creative ideas, personal and professional development courses, motivating salaries and bonuses when case maybe, organization of teambuilding. 
The importance of satisfied employees determines: efficiency of the activity, job satisfaction, the creation of a close and productive team; the talents remain in the company, capable employees take on greater responsibilities and the working environment is favorable to development.

The need for financial management for the development of Human Resources Management ensures the well-being of the Employees, long-term financial stability and the profitability of the organization.

The Human Resource is the only creator not only from an economic point of view but also from a spiritual, scientific point of view. The generation of new ideas embodied in products, technologies, management methods, new organizational solutions, is the exclusive privilege of the human being. The effectiveness and efficiency of the use of material and information resources depend to a large extent on Human Resources.

The practice of economic activity reveals many situations when enterprises similarly endowed from technical - financial and informational point of view or having very close levels, obtain noticeably different economic performances.

\section{"Are people born self-motivated or should the motivation be induced?"}

People are born with needs. From our point of view, the motivation is closely related to the need. The more the needs grow, the more the motivation to meet that need increases. If a company knows its employees and their needs very well, it can motivate them to achieve the desired performance and productiveness. The workforce is the only creator of usage value; in fact the company represents the basic economic cell of the company in which people create products and services.

\section{Acknowledgements}

This work was supported by the project "Excellence, performance and competitiveness in the R\&D\&I activities at "Dunarea de Jos" University of Galati", acronym "EXPERT", financed by the Romanian Ministry of Research and Innovation, Programme 1 - Development of the national research and development system, Sub-programme 1.2 - Institutional Performance - Projects for financing excellence in R\&D\&I, Contract no. 14PFE/17.10.2018.

\section{References}

1. Abraham H. Maslow (1954), Motivation and Personality.

2. Back D., (1985), Success in Small Business: the Role of the Financial Adviser, Longman Professional Sydney.

3. Burciu, A. (coord.) (2008), Introduction in management, Bucharest: Economica Publishing House.

4. Burns P., (1985), Financial characteristics of small companies in the UK, Cranfield School of Management.

5. Certo, S. C. (2002), Modern Management, Bucharest: Teora Publishing House.

6. Dasam Ragupathi, (2013), The Financial and Human Resource Management Strategies to Develop the Organization, Research Journal of Management Sciences_ISSN 2319-1171 Vol. 2(10), 6-9, October (2013) Res. J. Management Sci.

7. Deaconu, A. (coord.) (2008), Human Resources Management, Theory and practice, $2^{\text {nd }}$ edition, Bucharest: Economica Publishing House.

8. Dinica, L., Mihai I.O., Isai, V.M., (2019), Diagnosis and Perspectives of Accounting in EU Countries, Economics and Applied Informatics, "Dunarea de Jos" University of Galati, Faculty of Economics and Business Administration, issue 2, pages 63-68.

9. Douglas McGregor, (1960), The Human Side of Enterprise.

10. Diaz-Serrano, L., Cabral Vieira, J.A., (2005), Low Pay, Higher Pay and Job Satisfaction within the European Union: Empirical Evidence from Fourteen Countries. IZA Discussion Paper No. 1558.

11. Elliott J.W., (1972) Control, size, growth and financial performance in the firm, Journal of Financial and Quantitative Analysis, 7, 130920.

12. Florea, A.-M.; Capatina, A.; Radu, R.I.; Serban (Bacanu), C.; Boboc, M.G.; Stoica (Dinca), C.; Munteanu (Pila), M.; Ion (Dumitriu), I.M.; Stanciu, S. (2019a), Limiting Factors that Influence the Formation of Producer Groups in the South-East Region of Romania: A Fuzzy Set Qualitative Comparative Analysis (fSQCA). Sustainability, 11, 1614.

13. Florea, A.-M.; Bercu, F.; Radu, R.I.; Stanciu, S. (2019b) A Fuzzy Set Qualitative Comparative Analysis (fsQCA) of the Agricultural Cooperatives from South East Region of Romania. Sustainability, 11, 5927.

14. Gavrilă, T. and Lefter, V. (2004), General Company Management, $2^{\text {nd }}$ Edition, Bucharest: Economica Publishing House.

15. Hoffman, O., Popescu, N. G. (2009), Methodology issues in the analysis of social realities, Bucharest: University Publishing House.

16. Huselid M.A., (1995), The impact of Human Resource Management practices on turnover, productivity, and corporate financial performance, Academy of Management Journal, 38(3), pp. 635-672.

17. Isai V., Mihai I.O., Milica G., (2014), Study regarding the financing and taxation of the Romanian Non-Governmental Organizations, International Conference "Risk in Contemporary Economy" ISSN-L 2067-0532 ISSN online 2344-5386 XVth Edition, Galati, Romania, "Dunarea de Jos" University of Galati - Faculty of Economics and Business Administration.

18. Muscalu E. and Muntean S. Motivation (2012), A Stimulating Factor for Increasing Human Resource Management Performance, Business Excellence and Management Volume 2 Issue 1.

19. Onica, M.C., (2013), Corporate Governance Codes - Examples Of Good Practice, Risk in Contemporary Economy, "Dunarea de Jos" University of Galati, Faculty of Economics and Business Administration, pp. 172-178.

20. Onica M, (2009), Business analysis, "Europlus" Publishing House, Galati.

21. Onica, M., (2016), The Approach based on the Income in the Context of the Real Estate Ownership, Risk in Contemporary Economy, "Dunarea de Jos" University of Galati, Faculty of Economics and Business Administration, pages 385-392.

22. Proctor, M.D., Canada J.R., (1992), Past and present methods of manufacturing investment evaluation: A review of the empirical and theoretical literature, The Engineering Economist, pp. 38, 45-62.

23. Romualdo D., Anthony and Vijay Gurbaxani, (1998), Strategic Intent for IT Outsourcing, Sloan Management Review, p. 39.

24. Zlate, M., (2007), Organizational - Managerial Psychology Treaty, vol. II, Polirom Publishing House, Iaşi, vol. II, pp. $387-389$. 